Article

\title{
The Naturalized and Dialectical Ontologies of Nietzsche and Nishida
}

Kelly Louise Rexzy P. Agra

\begin{abstract}
This paper brings together the ontologies of two philosophers, Friedrich Nietzsche and Kitaro Nishida, in order to provide an alternative ontology different from the one that is founded in metaphysics. Nietzsche's philosophy provides a naturalized ontology, while Nishida's philosophy provides a dialectical ontology. Their philosophies are very different in form and objective, but they converge in at least two points: the ontological claims of (1) immanence and (2) transitoriness.
\end{abstract}

Keywords: Nietzsche, Nishida, naturalized ontology, dialectical ontology

"When your heart is ever open, and your spirit, free, your receptivity becomes infinite. Once you close it, it is the end of philosophical life." 1

7 he experimental aim of this paper is to bring together the ontologies of two philosophers, Friedrich Nietzsche and Kitaro Nishida, and see how they may provide an alternative ontology different from the one that is founded in metaphysics. In this paper, I present Nietzsche's philosophy as one that provides a naturalized ontology, and Nishida's philosophy as one that provides a dialectical ontology. After doing this, I then argue that although their philosophies are very different in form and objective, they nonetheless converge in at least two ontological claims: immanence and transitoriness.

${ }^{1}$ This is a statement by Alfredo P. Co in one of his lectures on Chinese Philosophy during the first semester of academic year 2011-2012, at the University of Santo Tomas, Manila, Philippines.

(c) 2019 Kelly Louise Rexzy P. Agra

https://www.kritike.org/journal/issue 25/agra december2019.pdf

ISSN 1908-7330

$(c c)$ BY-NC-ND 


\section{NIETZSCHE AND NISHIDA}

\section{Nietzsche's World of Immanence}

"The world ... is in all eternity chaos," 2 says Friedrich Nietzsche in his immanent critique of traditional metaphysics and western morality. His radical overturning of Plato's ontology of transcendence ${ }^{3}$ brings to the fore a "new image of thought" that gives credence to the world's apparent materiality, anthropomorphism, temporality, and chaos. Gilles Deleuze calls this counter ontology, an ontology of immanence. As opposed to a metaphysics of Being and Permanence, Nietzsche dares to challenge the "last man" to face the post human condition, and recognize the death of "God" the symbolic representation of metaphysics itself, its highest conceptsignaling the end of metaphysics, in order to affirmatively embrace a dedeified reality, reality de-conceptualized.

Nietzsche violently beats the bell with a hammer in order to wake philosophy up from its illusion of transcendence. ${ }^{4}$ In his Philosophy in the Tragic Age of the Greeks, he speaks of the Parmenidean prayer which goes:

Grant me, ye gods, but one certainty .... and if it be but a $\log ^{\prime}$ 's breadth on which to lie, on which to ride upon the sea of uncertainty. Take away everything that comes-tobe, everything lush, colourful, blossoming, illusory, everything that charms and is alive. Take all these for yourselves and grant me but one and only, poor empty certainty. ${ }^{5}$

Nietzsche criticizes the Parmenidean escape from the world in order to attribute reality to the logical, empty, and pale concept of being, the sole arbiter of essence. He attacks Western philosophy's obsession with permanence and transcendence, celebrated in the notion of God, in the

\footnotetext{
2 Friedrich Nietzsche, The Gay Science, trans. by Walter Kaufman (New York: Vintage Books, 1967), 109. To be cited as GS hereafter.

3 Paolo Bolaños, in a thesis entitled "On Affirmation and Becoming: A Deleuzian Reading of Nietzsche's Critique of Nihilism" claims that the overturning of Platonic metaphysics is the other half of the cure Nietzsche offers to the predicament that is nihilism, with the other half being his ethics of affirmation. See Paolo Bolaños, "On Affirmation and Becoming: A Deleuzian Reading of Nietzsche's Critique of Nihilism" (Master's Thesis, Brock University, Canada, 2005).

${ }^{4}$ Paolo A. Bolaños, "Nietzsche and the Ethological Conception of Ethics," in Minerva 11 (2007), 114.

${ }^{5}$ Friedrich Nietzsche, Philosophy in the Tragic Age of the Greeks trans. by Marianne Cowan (USA: Regnery Publishing, Inc., 1998), 11. To be cited as PTAG hereafter.
}

(c) 2019 Kelly Louise Rexzy P. Agra

https://www.kritike.org/journal/issue 25/agra december2019.pdf

ISSN 1908-7330

(c) $)$ BY-NC-ND 
Platonic world of forms ${ }^{6}$, or the Cartesian ${ }^{7}$ and Kantian ${ }^{8}$ rational certainty. He goes against the 'Idea's' "triumph over the world and the claims of the senses" 9 in Western philosophy, that is, the valorization of the Idea at the expense of matter. In Western philosophy, matter had always been regarded as the reluctant, recalcitrant, and resistant element, it had often been regarded as that which obstructs the absolute actualization of ideas or forms. ${ }^{10}$

In addition to the Nietzschean declaration of the death of God, he speaks of the "Destiny of the Soul."11 If Nietzsche attacks the highest ontological concept God, he is equally audacious in his criticisms towards the soul-one of the most valued concepts of subjectivity both in ethics and epistemology in Ancient, Medieval, and Modern philosophies. The reach of metaphysical thinking in ethics and epistemology, through the concept of the soul, has, for Nietzsche, made us forget about the nobility of the body. He stresses how the soul is so unknown and unreachable, and yet it reigns supreme in the realm of morality, in the kingdom of Reason, ${ }^{12}$ in metaphysika. ${ }^{13}$ What Nietzsche's counterculture intends to bring is the reversal of

${ }^{6}$ In Phaedo, Socrates is presented saying, "I speak not of these [absolute beauty and absolute good] alone, but of absolute greatness, and health, and strength, and of the essence or true nature of everything." Plato, Phaedo, in Dialogues of Plato, trans. Benjamin Jowett (New York: Simon and Schuster Paperbacks, 2010), 65e.

${ }^{7}$ René Descartes was in search for "the first principle of philosophy" which no ground of doubt would be capable of shaking, and he found this in the certainty of his own existence, thus writing the famous phrase: "Cogito ergo sum." See René Descartes, Discourse on the Method of rightly conducting the Reason and seeking Truth in the Sciences, trans. by Laurence J. Lafleur (New York: Liberal Arts Press, 1956), Chapter IV.

${ }^{8}$ In Immanuel Kant's Preface for the first edition of the Critique of Pure Reason, he writes, "It is ... a powerful appeal to reason to undertake anew the most difficult of its tasks, namely that of self-knowledge, and to institute a court of appeal which should protect reason in its rightful claims, but dismiss all groundless pretentions, and to do this ... according to the eternal and unalterable laws of reason. This court of appeal is none other than the critique of pure reason itself. ... Hence, I mean by this the decision about the possibility or impossibility of metaphysics in general, and the determination of its sources, its range and its limits - and all this according to principles." Immanuel Kant, Critique of Pure Reason trans. Marcus Weigelt, based on the translation of Max Müller (London, England: Penguin Books, 2007), 7.

${ }^{9}$ Nietzsche, $P T A G, 12$

10 See Christine Korsgaard, The Sources of Normativity (Cambridge: Cambridge University Press, 1996).

${ }^{11}$ Friedrich Nietzsche, Preface to On the Genealogy of Morals, trans. by Walter Kaufman and R.J. Hollingdale in On the Genealogy of Morals and Ecce Homo, trans. and ed. by Walter Kaufmann (New York: Vintage, 1989), § 7. To be cited as GM hereafter.

${ }^{12}$ Bolaños comments, 'God,' is just another term for Reason. Bolaños, "Nietzsche and the Ethological Conception of Ethics,” 114.

${ }^{13}$ Literally translated as beyond the physical. In What is Called Thinking?, Heidegger explains the transformation of the concept of metaphysics as the overcoming of what is physical or natural: "Man conceived as the rational animal is the physical exceeding the physical - that is, man raising himself above the animal, the sensual, the physical that he is, through reason, - in short: in the nature of man as the rational animal, there is the passing from the physical to the

(c) 2019 Kelly Louise Rexzy P. Agra

https://www.kritike.org/journal/issue 25/agra december2019.pdf

ISSN 1908-7330 
the metaphysical overcoming of physical nature - to bring the body back to life, as well as to bring life back to the body. Rather than treating the body as the reluctant, recalcitrant, and resistant obstacle to the soul, Nietzsche's philosophy would go as far as to assert how there is only the body. He describes the body as "living and corporeal, through which and over and beyond which a tremendous inaudible stream flow." 14 It is, for him, "the most astonishing idea"15 in which there is more wisdom than in the deepest philosophy. Nietzsche writes: "Body am I entirely, and nothing else; and soul is only a word for something about the body." 16

The body for Nietzsche is "composed of a plurality of irreducible forces, a multiple phenomenon, a unity of domination." 17 Deleuze elaborates this and explains that it is a product of chance, an assemblage of forces that have thus affected, influenced, and shaped it. These forces are classified into two: active force and reactive force. The active force is what the noble or the master expends from its affirmative power. The reactive force is what the slave expends from its negative power. While the former is creative, the latter is reactive. The body as an assemblage of the forces that it expends and receives within radically contingent contexts makes it a dynamic composition, a singularity molded by other singularities. This is radically different from the soul, conceived as determined, atemporal, static, transcendent, complete, and immaterial; confined within a corporeal body that prevents its realization. At the same time, while it is open to being affected, it is also always and already affecting. Through this naturalized anthropological-philosophical claim, history and the world would be seen as an ever-dynamic immanent play of forces. It is on this account that Deleuze refers to Nietzsche's philosophy as a philosophy of "pure immanence."18

From this immanentization of bodies, history, and the world, one could already surmise how Nietzsche's thinking differs from dominant strands of philosophical thinking before his time. It is this discussion of the body which anchors Nietzsche's account of the immanence of life and will to

non-physical, the supra-physical: thus man himself is the metaphysical." Martin Heidegger, What is called thinking? trans. by J. Glenn Gray (New York: Perennial, 2004), 58.

${ }^{14}$ Friedrich Nietzsche, Will to Power trans. Walter Kaufman and R. J. Hollingdale (New York: Vintage Books, 1967), 659. To be cited as WP hereafter.

${ }^{15}$ Ibid., 659.

${ }^{16}$ Friedrich Nietzsche, Thus Spoke Zarathustra trans. by Walter Kaufman, in The Portable Nietzsche (New York: The Viking Press, 1954), I, 4. To be cited as TSZ hereafter.

17 Gilles Deleuze, Nietzsche and Philosophy trans. by Hugh Tomlinson (New York: Columbia University Press, 2006), 40. Deleuze echoes here the Spinozistic bend of Nietzsche in relation to the body "that we do not even know what a body can do, we talk about consciousness and spirit and chatter on about it all, but we do not know what a body is capable of, what forces belong to it or what they are preparing for." To be cited as NP hereafter.

18 See Gilles Deleuze, Pure Immanence: Essays on a Life, trans. by Anne Boyman (New York: Zone Books, 2005).

(c) 2019 Kelly Louise Rexzy P. Agra

https://www.kritike.org/journal/issue 25/agra december2019.pdf

ISSN 1908-7330

(cc) BY-NC-ND 
power - towards which, according to him, all philosophies should be directed. He writes, "What are our evaluations and moral tables really worth? What is the outcome of their rule? For whom? in relation to what? - Answer: for Life." 19 For Nietzsche, life is the organic origin of all philosophizing. Even a philosophy of transcendence could only be the product of the internal dynamism of the play of forces within the pure immanence of life itself. The transcendent realm is in his rendering the world of fiction that falsifies, devalues, and negates reality, ${ }^{20}$ created out of the longing for deliverance from the drudgery of meaningless suffering and the transitoriness of phenomena:

Once the concept of "nature" had been invented as the opposite of "God," "natural" had to become a synonym of "reprehensible": this whole world of fiction is rooted in hatred of the natural (of reality!); it is the expression of a profound vexation at the sight of reality". ${ }^{21}$

If life for Nietzsche is the most basic ontological fact, the ground of our values and cogitations, the raison d'être of our necessary illusions - a life inseparable from a world ${ }^{22}-$ he then adds that where there is life, so there is will to power. ${ }^{23}$ Will to power, for Nietzsche, is the necessary condition of valuing in

${ }^{19}$ Nietzsche, $W P, 254$.

${ }^{20}$ Deleuze elaborates: "Life takes on the value of nil insofar as it is denied and depreciated. Depreciation always presupposed a fiction: it is by means of fiction that something is opposed to life. The whole of life then becomes unreal, it is represented as appearance, it takes on a value of nil in its entirety. The idea of another world, of a supersensible world in all its forms (God, essence, the good, truth), the idea of values superior to life, is not one example among many but the constitutive element of all fiction." Deleuze, NP, 147.

${ }^{21}$ Friedrich Nietzsche, The Antichrist, trans. by H.L. Mencken (Auckland: Floating Press, 2010), 15.

${ }^{22}$ Martin Heidegger speaks of this inseparability of life and world, he writes, "The phenomenological category, 'world,' immediately names what is lived, the content aimed at in living, that which life holds to...'life' and 'world' are not two separate self-subsistent Objects. ... World is the basic category of the content-sense in the phenomenon life." Martin Heidegger, Phenomenological Interpretations of Aristotle: Initiation into Phenomenological Research, trans. by Richard Rojcewicz (Bloomington, IN: Indiana University Press, 2001), 65.

${ }^{23}$ Nietzsche, TSZ, II, 12: "Where I found the living, there I found will to power. Only, where Life is, there is too will: though not will to life, but so I teach you - will to power!" See also Friedrich Nietzsche, Beyond Good and Evil, trans. by R.J. Hollingdale (London, England: Penguin books, 1990). To be cited as BGE hereafter. "The world seen from within, the world described and defined according to its 'intelligible character' - it would be 'will to power' and nothing else" (Nietzsche, BGE, 36); "A living thing desires above all to vent its strength - life as such is will to power" (ibid., 13); "... it will have to be the will to power incarnate, it will want to grow, expand, draw to itself, gain ascendancy - not out of any morality or immorality, but because it lives, and because life is will to power" (ibid., 259). "But what is life? Here we need a new, more definite formulation of the concept life. 'My formula for it is: Life is will to power'" (Nietzsche, WP, 258);

(c) 2019 Kelly Louise Rexzy P. Agra

https://www.kritike.org/journal/issue 25/agra december2019.pdf

ISSN 1908-7330 
general. It is what makes possible every willing, such that every commanding and obeying that occur within the arena of social interaction and cultural life is the reflection of the interplay of wills to power:

In all willing, it is absolutely a question of commanding and obeying, on the basis... of social structure composed of many "souls". 24

"Life" would be an enduring form of process of establishment of force, in which the different contenders grow unequally. To what extent resistance is present even in obedience; individual power is by no means surrendered. In the same way, there is in commanding an admission that the absolute power of the opponent has not been vanquished, incorporated, disintegrated. "Obedience" and "commanding" are forms of struggle..$^{25}$

Deleuze describes the will to power as the principle of synthesis of forces. It is never separable from force but is neither superior nor identical with it, and is always changing. ${ }^{26}$ If chance is the bringing of forces into relation, the will to power is the determining principle of this relation. ${ }^{27}$ It is "the plastic principle that is no wider than what it conditions, that changes itself with the conditioned and determines itself in each case along with what it determines." 28 What such conception of will to power stresses is the plasticity of the body and even life itself. The body, as a synthesis of forces, is never fixed; it is a living struggle of forces whose relation is that of domination. What dominates is the active force. What is subjugated is the reactive force. These two qualities of force, Deleuze interprets, emanate from the two qualities of power: affirmative or negative. As explained earlier, an affirmative power expends an active force that creates and sustains an ascending mode of life. Meanwhile, negative power expends a reactive force that creates and sustains a descending mode of life. Deleuze writes,

\footnotetext{
"a new definition of the concept life as will to power" (ibid., 617). Cf. Friedrich Nietzsche, La Volente de Puissance, trans. by G. Bianquis (from the edition of F. Wurzbach), I 204, II 54 in Deleuze, NP, 49: "Who therefore will power? an absurd question, if being is by itself will to power."

${ }^{24}$ Nietzsche, BGE, 19.

${ }^{25}$ Nietzsche, WP, 642.

${ }^{26}$ Ibid., 50.

${ }^{27}$ Ibid., 53.

${ }^{28}$ Ibid., 50.

(c) 2019 Kelly Louise Rexzy P. Agra

https://www.kritike.org/journal/issue 25/agra december2019.pdf

ISSN 1908-7330

(c) BY-NC-ND
} 
Affirming and denying, appreciating and depreciating, express the will to power just as acting and reacting express force. (And just as reactive forces are still forces, the will to deny, nihilism, is still will to power: "... a will to nothingness, an aversion to life; but it is and remains a will!" 29 ) ... Affirmation is not action but the power of becoming active, becoming active personified. Negation is not simple reaction but a becoming reactive. ${ }^{30}$

This emphasis on the body and life, which are dialectically determined by will to power, gives birth to a chance-driven conception of the world, or a world without a preordered, predetermined transcendent essence. From the Nietzschean frame of thinking, transcendence is an illusion, the soul is an illusion. For him, these are symptoms of our anthropomorphization of reality. The body as a singularity, dynamically formed by the struggle of all the forces involved in the determination of an individual's being, character, and outlook, becomes a unique and irreplaceable unity of force. What this idea signifies is the destruction of the age-old belief in the universality of the soul that does not exist, or its modern version, reason. We are always and already differently demanded, enticed, restrained, and provoked by the "common mode of nutrition, we call life." 31 Nietzsche demands the realization that "there is no knowable world, and that what we purport to apprehend when we talk about the world is nothing but a relation of perspectives or a constellation of concepts" 32 borne out of our singularities. Truth, as he declares "is nothing but an anthropomorphic army of metaphors and metonymies!" 33 For Nietzsche, if there is anything real in our invented, anthropomorphized conceptions of the world, it is their material and contingent genesis from life itself. Our philosophical ruminations are the confessions and manifestations ${ }^{34}$ of how we understood and were made to understand our world, not as souls, but as bodies.

\section{Nishida's World of Dialectical Singularities}

If Nietzsche provides a picture of a world of chance and immanence in contrast to a world of permanence and transcendence, the Japanese

${ }^{29}$ Nietzsche, GM, III, 28.

${ }^{30}$ Deleuze, NP, 54 .

${ }^{31}$ Nietzsche, $W P, 641$.

${ }^{32}$ Paolo Bolaños, "From Rigidity to Receptivity: Articulating an Ethics of Thinking via Nietzsche and Adorno," in Representation and Contestation: Cultural Politics in a Political Century, ed. by John McSweeney and Ching-Yu Lin (Amsterdam/New York: Rodopi, 2010), 171.

${ }^{33} \mathrm{Ibid} ., 174$.

${ }^{34}$ Nietzsche, BGE, 5-6.

(c) 2019 Kelly Louise Rexzy P. Agra

https://www.kritike.org/journal/issue 25/agra december2019.pdf

ISSN 1908-7330 
philosopher Kitaro Nishida meanwhile paints a world of dialectical singularities in contrast to a unified world, determined and supported by absolute being. If Nietzsche declares the death of the absolute being God, Nishida substitutes absolute being itself with absolute nothingness. Except that for Nishida, absolute nothingness is not a substance of reality. To be precise, it is not a substance, but a place.

Nishida, in his writings, shows that reality is not ultimately determined nor perfectly formed and is rather found always in the place of absolute nothingness. ${ }^{35}$ The place of absolute nothingness, he describes, is the final "place of coming-to-be and passing away," 36 in which all reality is, all that is constituted and determined, and the wherein of contradictories. In his paradox-ridden characterization, he describes absolute nothingness as nothing other than reality, but is not reality ${ }^{37}-\mathrm{a}$ "determination without determinant," 38 a "form of the formless," 39 "a predicate that can never be a subject." 40 Absolute nothingness is that which makes possible the co-existence of things, but it has no existence in-itself distinct from the myriad manifestations of the historical world. ${ }^{41}$ Its circumference is nowhere but its center is everywhere.

Nishida sketches the world as a world of countless individual beings "standing-opposite-to-one-another," 42 a "mutually-acting-upon-oneanother," 43 and a "reciprocally-determining-one-another." 44 He explains this through the Buddhist notion of dependent origination and interconnectedness of things which asserts the impossibility of an ultimate grounding for the determination and constitution of the world. What Nishida presents is the relational emergence of a self with other selves, or a singularity with other singularities:

${ }^{35}$ Elmar Weinmayr, "Thinking in Transition: Nishida Kitaro and Martin Heidegger," trans. by John Krummel and Douglas Berger, in Philosophy East $\mathcal{E}$ West, 55:2 (April 2005), 235. [Quotations from Nishida coming from his Collected Works are copied from this article and Lucy Schultz's "Nishida Kitaro, G.W.F. Hegel, and the Pursuit of the Concrete: A Dialectic of Dialectics," in Philosophy East $\mathcal{E}$ West, 62:3 (July 2012), unless stated otherwise.]

${ }^{36}$ Nishida Kitaro, Collected Works of Nishida Kitaro (Tokyo: Iwanami Shoten, 1979), 4:219. To be cited as $C W$ hereafter.

${ }^{37}$ Weinmayr, "Thinking in Transition: Nishida Kitaro and Martin Heidegger," 235.

${ }^{38}$ Nishida, $C W, 8: 11$

${ }^{39}$ Ibid., 4:6

${ }^{40}$ James Heisig, Philosophers of Nothingness: An essay on the Kyoto School (Honolulu: University of Hawaii Press, 2001), 79.

${ }^{41}$ Schultz, "Nishida Kitaro, G.W.F. Hegel, and the Pursuit of the Concrete," 324.

${ }^{42}$ Nishida, CW, 8:17

${ }^{43}$ Ibid., 9:147

${ }^{44}$ Ibid., 8:65

(c) 2019 Kelly Louise Rexzy P. Agra

https://www.kritike.org/journal/issue 25/agra december2019.pdf

ISSN 1908-7330

(c) BY-NC-ND 
... the self is itself through the fact that it is mediated through an other. 45

It is not the case that there are initially independent singular things, which then connect. A singular thing is singular insofar as it stands against singular things. ${ }^{46}$

A singular thing is grounded in the reciprocal self-determination of countless singular things. ${ }^{47}$

In phenomenological terms, this could be understood as something similar to the concept of intersubjectivity, where subject and identity formation are reciprocally and dialectically achieved. With Nishida's reference to dependent origination, what arises is a dialectical selfdetermination, characterized by discontinuous continuity and contradictory self-identity. It makes possible a singularity's openness towards and recognition of other singularities that are not merely distinct from itself, nor merely occurring side by side with it, but are related with it in the form of a recognition of togetherness characterized by a reciprocal concern, consideration, appreciation and attention. It is a relation that is at the same time an acknowledgment of contingency, dependence, and transitory relational emergence. Elmar Weinmayr explains this Nishidan point on transitory relational emergence:

... through this transition it discovers itself in the other and the other in itself; both suffering a rupture and finding itself anew in this rupture ... there results a creative mediation-whether it is in mutual fitting together or in reciprocal self-determination-when neither of these individual worlds insists on mere "continuity" or the "boundless stubbornness of expanding into the merely persisting continuation" of its own tradition and form. Rather, in awareness of its "absolutely contradictory self-identity" in regard to its own lingering awhile and transitoriness in the encounter of its own continuity, it risks its "identity" and its selfunderstanding and thus in sum its own unforeseeable transformation and new determination. ${ }^{48}$

${ }^{45}$ Ibid., 8:85-86

${ }^{46}$ Ibid., 8:65

${ }^{47}$ Ibid., 8:56

48 Weinmayr, “Thinking in Transition: Nishida Kitaro and Martin Heidegger," 244.

(c) 2019 Kelly Louise Rexzy P. Agra

https://www.kritike.org/journal/issue 25/agra december2019.pdf

ISSN 1908-7330 


\section{NIETZSCHE AND NISHIDA}

Weinmayr notes that Nishida proceeds from the Buddhist doctrine that describes the fundamental way of existence of all beings: pratityasamutpada (Sanskrit) or engi (Japanese). The character en roughly means relation, dependence, connection; the sign $k i$ or gi means origination, literally, "dependent origination" or "relational emergence." This means that no being can exist only for itself; it is always only in relation to all the others. ${ }^{49}$ What these countless interdependent singularities form is a world, a universal that preserves and embraces their self-negating determination. In the thought of Nishida, this is possible only because what supports the manifold is not absolute being but absolute nothingness, the empty in-between of singularities that separates and holds them together at the same time.

In talking about life in relation to dependent origination, Nishida once again uses a counter intuitive phrase "living by dying." 50 This idea rests on the appreciation that "all things alter and pass away" and that "nothing is eternal or infinite." 51 What this means is that nothing can ever persist without negation. No singularity can discover itself without losing itself. Everything requires the dialectical coexistence of the self and other selves. For Nishida, it is a contradiction, but our existence consists exactly of the contradiction that our way of persisting is through dying. ${ }^{52}$ Lucy Schultz explains this dialectical take on life:

The lives of individuals are dialectical because they persist through negation, and one way that negation is lived out is through the passage of time. For Nishida, the individual becomes individual through the negation of itself and, temporally speaking, negation can be understood as a kind of death. ${ }^{53}$

In this account of life, negation and contradiction become a constitutive process to the coming to presence and existence of things. To exist, from the word existare which means to "stand-out," means to arise from a negation, to be the retroactive result of negation-but where negation itself is that which does not exist, or exists only as that which comes to pass but is never directly visible or present. Negation is not an entity, instead, it is the movement, the

${ }^{49}$ Ibid.

50 "The individual ... has life. But the true individual not only has mere life. It lives by dying." Nishida Kitaro, Fundamental Problems of Philosophy, trans. by David Dilworth (Tokyo: Sophia University, 1970), 155.

${ }^{51}$ Nishida, $C W, 11: 408$

52 Ibid., 11:396

${ }^{53}$ Schultz, "Nishida Kitaro, G.W.F. Hegel, and the Pursuit of the Concrete," 327-328.

(c) 2019 Kelly Louise Rexzy P. Agra

https://www.kritike.org/journal/issue 25/agra december2019.pdf

ISSN 1908-7330

(c) $\mathrm{BY}-\mathrm{NC}-\mathrm{ND}$ 
activity, the being in transition of that which exists. ${ }^{54}$ And this dialectical negation that brings entities into presence and existence takes place in absolute nothingness.

\section{Naturalized and Dialectical Ontology}

\section{Argument on Immanence}

Looking at the underlying theme that directs the philosophies of both Nietzsche and Nishida, one gets a sense of thinking that veers away from the traditional philosophy of Being, permanence, essence, and transcendence. In both of their philosophies, thoughts and the world are not claimed to be constituted by something that is beyond, ecstatic, and complete. For both Nietzsche and Nishida, thoughts and the world are immanently conditioned and determined. As Nishida writes:

When one speaks of acting, one starts from the individual subject. But we do not act from outside the world. Rather we find ourselves, when acting, already within the midst of the world. Our acting is beingacted. 55

Meanwhile, Nietzsche writes:

It is essential that one should not make a mistake over the role of "consciousness": it is our relation with the "outer world" that evolved it .... Usually, one takes consciousness itself as general sensorium and supreme court; nonetheless, it is only a means of communication: it is evolved through social intercourse -"Intercourse" here understood to include influences of the outer world and the reactions they compel on our side; also our effect upon the outer world. ${ }^{56}$

\footnotetext{
${ }^{54}$ This is almost similar to G.W.F. Hegel's view of negation in Science of Logic: "against contradiction, identity is merely the determination of the simple immediate, of dead being ... contradiction is the root of all movement and vitality; it is only insofar as something has contradiction within it that it moves, has an urge, and activity." G.W.F. Hegel, Science of Logic trans. by A.V. Miller (New York: Humanity Books, 1969), 439.

${ }^{55}$ Nishida, $C W$, 9:167

${ }^{56}$ Nietzsche, WP, 524.
}

(c) 2019 Kelly Louise Rexzy P. Agra

https://www.kritike.org/journal/issue 25/agra december2019.pdf

ISSN 1908-7330 
The world as a discontinuous continuity becomes, what Deleuze calls, the chaosmos - an understanding of the world as something characterized by contingency rather than necessity, and by the absence of a pre-determined order. In Nishida's philosophy, one understands that "historical reality transforms itself without an underlying substance or ground." 57 The environing world with its dialectical matrix brings about the "concrete reality of life." 58 Meanwhile, for Nietzsche, the world appears chaotic based on the testimony of the senses. It "lacks order, arrangement, form, beauty, wisdom, and whatever names there are for our aesthetic anthropomorphisms; it is neither perfect nor beautiful, nor noble, nor does it wish to become any of these things; its total character, is in all eternity chaos." 59

In Nietzsche's naturalized ontology, we become bodies that must be awakened from our transcendental delusions and "despair of the earth." 60 For him, there is no other-world, a world of forms, or a world in-itself. We only have a perspectival image of it. ${ }^{61}$ "Depending on where we are coming from, we may interpret the world as 'deified' (descending) or 'naturalized' (ascending). As opposed to the deified view which sees an ordered, well organized universe, Nietzsche's naturalism sees the world as basically chaotic." 62

On the other hand, for Nishida, the world is the absolutely contradictory self-identity of the one [world] and the many [singularity]. "As one and universal, the world embraces the many singulars, mediates them mutually among themselves, and thus offers to all singulars a place within which they stand in relation to one another, affect one another, are mutually constituted, and thus first able to be as singulars." 63 This world has no center; its unity and continuity are perpetually destroyed. ${ }^{64}$ Nishida emphasizes the non-separability of the human subject and the objective world and affirms the world and the self's dialectical determination. He writes:

57 Nishida, CW, 11:389. Nishida writes, “... no matter how much a man born into a certain society were rich in originality, he would always receive the control of its particular social spirit." Kitaro Nishida, Zen no Kenkyu, in Lothar Knauth "Life is Tragic. The Diary of Nishida Kitaro," in Monumenta Nipponica, 20:3/4 (1965), 347. Nishida, CW, 8:27: “.. our life is a constitutive act in which the world constitutes itself." Ibid., 8:86: "Our acting is a constitutive act of the historical world."

${ }^{58}$ Nishida, CW, 8:19.

${ }^{59}$ Nietzsche, GS, 109. Citation modified.

${ }^{60}$ Nietzsche, TSZ I, 3.

${ }^{61}$ Bolaños, “On Affirmation and Becoming," 109.

${ }^{62}$ Ibid.

${ }^{63}$ Weinmayr, "Thinking in Transition: Nishida Kitaro and Martin Heidegger,"241.

${ }^{64} \mathrm{Ibid}$.

(c) 2019 Kelly Louise Rexzy P. Agra

https://www.kritike.org/journal/issue 25/agra december2019.pdf

ISSN 1908-7330

(c) BY-NC-ND 
The broken self-identity of the world means that the one world "has its identity in the many singulars." 65 In other words, what the world is, the form of the world, is determined out of the reciprocally constituting occurrence of all beings and their connection of effects. Alternatively, the continuous self-determination and self-constitution of singulars is none other than a selfdetermination and self-constitution of the placially mediating, the world. ${ }^{66}$

For Nietzsche, bodies are assemblages of forces. For Nishida, singularities are interdependently determined. For Nietzsche, the dynamic intercourse of forces take place in immanent life. For Nishida, dependent origination take place in absolute nothingness. Their views are not exactly parallel, but they are, to a certain level, compatible.

\section{Argument on Transitoriness}

What is furthermore significant to point out in the different descriptions of the world found in the writings of Nietzsche and Nishida, as naturalized and dialectical respectively, is not only their common recognition of immanent reality, but also its transitory character. To an extent, Nishida could be said to be describing the place of becoming, while Nietzsche describes the process of becoming; both, nevertheless, highlight the place and the movement of becoming as transitory.

Instead of absolute being, Nishida refers to the place of absolute nothingness, which he describes as the place of coming-to-be and passing away, or what he refers to as the "placial mediation" ${ }^{67}$ of life (being) and death (nothingness). Life and death, being and nothingness, for Nishida, exist not in a fused concurrence, but as completely independent, contrasting, and thoroughly discontinuous singulars. The image of the Chinese concepts of Yin and Yang is almost analogous to what Nishida describes. However, despite the distinction between life and death, being and nothingness, Nishida stresses their dialectical interdependence. He explains that their interdependence comes to light through their dialectical movement, which in a "radical and fathomless sense" is an open and creative "movement from form to form," 68 and in which "the world of the contradictory self-identity of

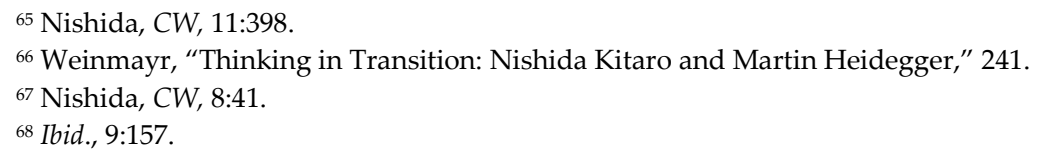




\section{NIETZSCHE AND NISHIDA}

the one and the many is completely groundless and endlessly constituted." 69 Within Nishidan philosophy, one cannot speak of being without immediately presupposing its dialectical relation with nothingness, and one cannot speak of life without immediately presupposing its dialectical relation with death, and these, being-nothingness and life-death is what constitute a reality that is forever in transition. Such transitoriness is manifest precisely because being and life are considered distinct from death and nothingness, and the relational movement of one form to another is what brings into presence [dialectical] reality.

This resonates well with Nietzsche's emphasis on the affirmation of passing away and destroying, of opposition and war, i.e., of becoming, along with a radical repudiation of the very concept of being. ${ }^{70}$ He echoes Heraclitus in saying that "Out of the war of opposites all Becoming originates; the definite and to us seemingly persistent qualities express only the momentary predominance of the one fighter, but with that the war is not at an end; the wrestling continues to all eternity." 71 Nietzsche further writes: "If the universe were capable of permanence and fixity, and if there were in its entire course a single moment of being in the strict sense it could no longer have anything to do with becoming, thus one could no longer think or observe any becoming whatever."72 It must be noted however that, for Nietzsche, being and becoming are not opposites per se. Nor do they stand side by side, like being and nothingness. For Nietzsche, everything is becoming, but this becoming "returns," is repeated, it "recurs," though never in the same way. This is another reference to the Heraclitan phrase of not being able to step into the same river twice. This is referred to in Nietzsche's philosophy as "eternal recurrence." Deleuze explains: "Returning is the being of that which becomes: It is not being that returns but rather the returning itself is what constitutes being insofar as it is affirmed of becoming and of that which passes." 73 In a similar fashion to Nishida, the concept of eternal recurrence gives the insight that being seems to come into presence only because it is becoming, it is flux.

What is important to note here is how Nishida's "place of absolute nothingness" beautifully supplements this Nietzschean position of eternal recurrence. If we are to risk an interpretation of the implication of their thoughts, we can say that being recurs in the place of absolute nothingness. The place of absolute nothingness, the place of coming to be and passing

\footnotetext{
${ }^{69}$ Ibid., 11:400. 243

${ }^{70}$ Friedrich Nietzsche, Ecce Homo, trans. and ed. by Walter Kaufman, in Basic Writings of Nietzsche (New York: Modern Library, 2000), III, 1.3.

${ }^{71}$ Nietzsche, PTAG, 5.

72 Nietzsche, $W P$, 322. See analogous text 1062.

${ }^{73}$ Deleuze, NP, 48.

(c) 2019 Kelly Louise Rexzy P. Agra

https://www.kritike.org/journal/issue 25/agra december2019.pdf

ISSN 1908-7330
}

(cc) BY-NC-ND 
away, is the place of becoming. It is referred to as a "place" and not a "state", since again, for Nishida, reality is groundless. In addition, Nishida quite interestingly speaks of a concept almost similar to Nietzsche's eternal recurrence, that of the "eternal now/present." He writes:

In each and every action [the individual] faces the absolute [eternal now] .... Generally, the moment is thought of as a linear point passing from past to future. But such an idea is simply an abstraction. From the perspective of time, as the self-determination of the eternal now, the present becomes an arc of an infinitely large circle. The passing moment exists at the ultimate point of such an arc. Therefore, the present has a breadth. Human existence is also like this. ${ }^{74}$

The world of reality is the self-determination of the eternal present. ${ }^{75}$

This powerful statement from Nishida, "the world of reality is the selfdetermination of the eternal present" echoes well with Nietzsche's references to eternal recurrence: "That everything recurs is the closest approximation of a world of becoming to a world of being."76 Reality's self-determination is akin to the process of becoming itself. Meanwhile, the eternal recurrence of things is translated in temporal terms as the eternal present. This selfdetermination and becoming that eternally recurs and appears as the eternal present is the approximation of being. It is what seems to give it some form or consistency despite, but also in lieu of, its transitoriness. But again, being here is used differently from Being as the absolute principle of reality, or the notion of Being as the alpha and omega of all things. Being, in their sense, is not the origin or destination of things; it is only the chimerical effect of the recurrence of becoming-like the consistency of a flowing river, it is the same river, but different in every moment. It is the continuity of discontinuity and the discontinuity of continuity.

Nietzsche's naturalized and Nishida's dialectical ontologies, through eternal recurrence and the eternal present, both lead to a notion of time as circular. Eternity as temporal is another concept in their philosophies that is different from atemporal eternity in traditional philosophy. The eternal present coexists with the past and what is yet to come. ${ }^{77}$ This creates an idea

${ }^{74}$ Nishida, CW, 7: 231-232.

75 Ibid., 7: 231.

${ }^{76}$ Nietzsche, WP, 617.

77 Deleuze, NP, 48.

(c) 2019 Kelly Louise Rexzy P. Agra

https://www.kritike.org/journal/issue 25/agra december2019.pdf

ISSN 1908-7330 
of historical time as the eternal self-determination of the world whose movement is circular rather than linear.

\section{Conclusion}

Despite the difference in their language and approach to metaphysics, both Nietzsche's and Nishida's thoughts converge in at least two main points. First, the world and life are immanently constituted. Second, reality is transitory. Bringing these points together results to a view of existence as temporal, and of history as the eternal self-determination or becoming of the immanently constituted world. In addition, for both Nietzsche and Nishida, the world lacks justification. In fact, it doesn't need one. It is de-deified/naturalized and it is groundless. These two points are the ultimate consequences of their naturalized and dialectical ontologies. They provide an alternative, this-worldly, and magnanimous view of life and reality, which, in the words of Nietzsche, is symptomatic of the ascending/affirmative mode of life.

At the beginning of this paper, I have alluded to the argumentation's experimental nature. The objective was to bring together the ontological claims of two philosophers from different philosophical traditions in order to determine whether they could be instructive to our general philosophical understanding of the world, history, and ourselves. As argued, their two ontological positions complement one another. As Nietzsche asserts for a dedeified/naturalized reality, Nishida explains that this reality, constituted by multiple singularities, comes into presence through these entities' dialectical movement. As Nietzsche emphasizes becoming, Nishida provides elucidation for the place of becoming, such that de-deified/naturalized reality resonates with absolute nothingness, and dialectics resonates with becoming. Finally, this is supplemented by their almost similar notions of temporality, namely, eternal recurrence and eternal now/present.

Criticisms and counter interpretations aside, what these similarities bring to light is the possibility of agreements between thinkers from different cultural traditions, temporal time frame, and religious convictions. This, I assert, is the ethical commitment of comparative approaches in philosophy. In the spirit of Alain Badiou's philosophy, I argue that to mark and emphasize that difference does not require much thinking, for alterity is simply what there is. ${ }^{78}$ What requires effort and moral commitment, however, is the establishment of forms of unity. As Badiou stresses: unity is a result and never

${ }^{78}$ Alain Badiou, Ethics: An Essay on the Understanding of Evil, trans. by Peter Hallward (New York: Verso, 2000), 26. In French, the expression "what there is" is translated as "q'est il y a" which refers to a 'state of being.'

(c) 2019 Kelly Louise Rexzy P. Agra

https://www.kritike.org/journal/issue 25/agra december2019.pdf

ISSN 1908-7330

(c) $\mathrm{BY}-\mathrm{NC}-\mathrm{ND}$ 
a given. ${ }^{79}$ Thus, to be able to see that unity is possible, even at the level of pure thought, must be a source of hope. Philosophizing must at least be able to provide such hope. Bringing Nietzsche's and Nishida's philosophies together is an attempt to realize exactly this philosophical desire.

Department of History and Philosophy, University of the Philippines-Baguio, Philippines

\section{References}

Badiou, Alain, Being and Event, trans. by Oliver Feltham (New York: Continuum, 2005). Ethics: An Essay on the Understanding of Evil, trans. by Peter Hallward (New York: Verso, 2000).

Bolaños, Paolo, "From Rigidity to Receptivity: Articulating an Ethics of Thinking via Nietzsche and Adorno," in Representation and Contestation: Cultural Politics in a Political Century, ed. by John McSweeney and Ching-Yu Lin (Amsterdam/New York: Rodopi, 2010).

"Nietzsche and the Ethological Conception of Ethics," in Minerva 11 (2007).

"On Affirmation and Becoming: A Deleuzian Reading of Nietzsche's Critique of Nihilism" (Master's Thesis, Brock University, Canada, 2005).

Deleuze, Gilles, Nietzsche and Philosophy trans. by Hugh Tomlinson (New York: Columbia University Press, 2006).

Pure Immanence: Essays on a Life, trans. by Anne Boyman (New York: Zone Books, 2005).

Descartes, René, Discourse on the Method of rightly conducting the Reason and seeking Truth in the Sciences, trans. by Laurence J. Lafleur (New York: Liberal Arts Press, 1956).

Hegel, G.W.F., Science of Logic trans. by A.V. Miller (New York: Humanity Books, 1969).

Heidegger, Martin, Phenomenological Interpretations of Aristotle: Initiation into Phenomenological Research, trans. by Richard Rojcewicz (Bloomington, IN: Indiana University Press, 2001).

What is called thinking? trans. by J. Glenn Gray (New York: Perennial, 2004).

${ }^{79}$ See Alain Badiou's Being and Event, trans. by Oliver Feltham (New York: Continuum, 2005).

(C) 2019 Kelly Louise Rexzy P. Agra

https://www.kritike.org/journal/issue 25/agra december2019.pdf

ISSN 1908-7330

(cc) BY-NC-ND 
Heisig, James, Philosophers of Nothingness: An essay on the Kyoto School (Honolulu: University of Hawaii Press, 2001).

Kant, Immanuel, Critique of Pure Reason trans. Marcus Weigelt, based on the translation of Max Müller (London, England: Penguin Books, 2007).

Korsgaard, Christine, The Sources of Normativity (Cambridge: Cambridge University Press, 1996).

Nietzsche, Friedrich, Beyond Good and Evil, trans. by R.J. Hollingdale (London, England: Penguin books, 1990). Ecce Homo, trans. and ed. by Walter Kaufman, in Basic Writings of Nietzsche (New York: Modern Library, 2000).

On the Genealogy of Morals, trans. by Walter Kaufman and R.J. Hollingdale in On the Genealogy of Morals and Ecce Homo, trans. and ed. by Walter Kaufmann (New York: Vintage, 1989).

Philosophy in the Tragic Age of the Greeks trans. by Marianne Cowan (USA: Regnery Publishing, Inc., 1998).

The Antichrist, trans. by H.L. Mencken (Auckland: Floating Press, 2010).

The Gay Science, trans. by Walter Kaufman (New York: Vintage Books, 1967).

Thus Spoke Zarathustra trans. by Walter Kaufman, in The Portable Nietzsche (New York: The Viking Press, 1954).

Will to Power trans. Walter Kaufman and R. J. Hollingdale (New York: Vintage Books, 1967).

Nishida Kitaro, Collected Works of Nishida Kitaro (Tokyo: Iwanami Shoten, 1979).

Fundamental Problems of Philosophy, trans. by David Dilworth (Tokyo: Sophia University, 1970).

Zen no Kenkyu, in Lothar Knauth "Life is Tragic. The Diary of Nishida Kitaro," in Monumenta Nipponica, 20:3/4 (1965).

Plato, Phaedo, in Dialogues of Plato, trans. Benjamin Jowett (New York: Simon and Schuster Paperbacks, 2010).

Schultz, Lucy, "Nishida Kitaro, G.W.F. Hegel, and the Pursuit of the Concrete: A Dialectic of Dialectics," in Philosophy East $\mathcal{E}$ West, 62:3 (July 2012).

Weinmayr, Elmar, "Thinking in Transition: Nishida Kitaro and Martin Heidegger," trans. by John Krummel and Douglas Berger, in Philosophy East \& West, 55:2 (April 2005).

(c) 2019 Kelly Louise Rexzy P. Agra

https://www.kritike.org/journal/issue 25/agra december2019.pdf

ISSN 1908-7330

(c) $)$ BY-NC-ND 